\title{
A young lord passes judgment: National characters in the letters, poems and other writings of Byron's Mediterranean tour (1809-11)
}

\author{
Agustín Coletes Blanco \\ Universidad de Oviedo \\ coletes@uniovi.es
}

\begin{abstract}
On July $2^{\text {nd }}, 1809$, Lord Byron and his Cambridge friend John C. Hobhouse embarked on their peculiar Grand Tour. With most of Continental Europe in the hands of Napoleon, Byron and Hobhouse's destination was Constantinople, the capital of a powerful Ottoman Empire which still controlled much of Eastern Europe, North Africa and the Middle East. The travellers took a year to reach the Porte. Previous stages in their journey included Portugal, Spain, Gibraltar, Malta, Albania and Greece. Unlike Hobhouse, Byron was never to publish a travelogue based on his Mediterranean and Levantine experience. However, throughout his tour he did write many letters and occasional poems, not meant for publication, in which he repeatedly passes judgment on the Portuguese, the Spaniards, the Greeks, the Albanians and the Turks as national characters -and also on fellow countrymen abroad. In this paper, young Byron's judgments on said national characters, as manifested in his letters and poems home, are located, grouped together and analysed, for the first time in the literature, in a comprehensive way -thus bringing into question a number of commonlyheld misconceptions on the issue. Byron's own Childe Harold's Pilgrimage (the poem and its notes which, published soon after his Mediterranean experience, famously won him instant recognition in Britain) and Hobhouse's Journey to Albania and unpublished diary are, in the light of this essay, used as paratexts that enrich the analysis with added, sometimes diverging perspectives. In the light of such corpus, the essay closes with a
\end{abstract}


classification, an explanation and a summary of the consequences of young Byron's Mediterranean judgments.

Keywords: Lord Byron, travel writing, Romanticism, Imagology, Orientalism

George Gordon, Lord Byron, during his Mediterranean and Levant tour of 1809-1811, wrote a total of 92 letters, 28 occasional poems and 7 varia. ${ }^{1}$ Although not intended for publication in most cases, the texts are in reality travel writing and, as happens so frequently in texts of that kind, the young Byron often passes judgment on the national characters he comes across during his journey. ${ }^{2}$ Byron's early judgments on national identities have traditionally been associated with their echoes in various stanzas of Childe Harold's Pilgrimage (cantos I and II), the poem which, as part of the aftermath of his Mediterranean experience, was published in London, 1812, making its author, according to legend, instantly famous. ${ }^{3}$ However, the main contention in this essay is that in order to gain a greater insight into Byron's early vision of foreigners we should rather turn our attention to the letters which he wrote to various correspondents all along the tour. Less well-attended by the critics, these letters boast a wealth of interesting comments on the various national characters with whom the young lord came in touch. His comments are, at the least, as interesting as the opinions expressed in texts meant for publication. This is only logical: while Byron was at first unwilling to tell anyone about $C H P$, probably because he felt it revealed too much of himself ${ }^{4}$ (and we have plenty of evidence of censorship or suggestions to that effect during the editing process of $C H P),{ }^{5}$ the letters which Byron wrote to his mother and his friends during the tour had, of their own nature, been more spontaneous and less guarded than the later literary re-creations of the tour.

An initial point of interest is the fact that the national characters commented on by the traveller are not in this case the French or the Italians -as was common amongst the "grand tourists"- but the more exotic Portuguese, Spaniards, Maltese, Greeks, Albanians and Turks. The main reason was that at the time of Byron's tour practically the whole of Western and Central Europe was directly or indirectly in the hands of Napoleon. This meant that the canonical grand tour, with its itinerary across France, Switzerland, Italy, Germany and the Low Countries was simply out of the question for any traveller from England, not to mention a young lord who had just left Cambridge. ${ }^{6}$ Byron had turned 21 in January, and his decision was to embark with his close college friend, John Cam Hobhouse (later Lord Broughton) on a "tailored" Grand Tour, with an itinerary (basically by sea) which went along the very borders of Napoleon's Empire and as far away as the territory of another empire, the Ottoman, which at the time spread over much of South-Eastern Europe, including present-day Albania and Greece. So we have our travellers, Byron, and the slightly older Hobhouse, who will be Byron's faithful if somewhat fastidious companion during the first year of the tour, embarking on a journey which would actually last two years and 12 days, from July 2nd, 1809 to July $14^{\text {th }}, 1811 .^{7}$ The first stop was Lisbon, and they then proceed overland to Seville and Cádiz in Spain. From Gibraltar they continue sailing East and, after calling at 
Sardinia and Sicily, they enter the harbour of La Valetta in Malta at the end of August. Less than a month later the two friends are already in Greece, first in Patras and then in Preveza. Next they carry on North by land into the territory of present-day Albania. After this and other excursions, the travellers arrive in Athens on Christmas Day, 1809. They visit numerous places in Continental Greece, and, with the coming of spring, Byron and Hobhouse sail again, now bound for Asia Minor and Constantinople, where they stay for two months. From July 1810 until April 1811, Byron will settle again in Athens, while Hobhouse returns to England. ${ }^{8}$ Finally, it is Byron himself who, very reluctantly, sails back to England, where he arrives on July $14^{\text {th }}, 1811$. One of the most significant Byronic icons, often printed in editions of his works, is a portrait by George Sanders representing Byron and his page Rushton, posing as voyagers, which was actually commissioned by the poet before he left for his Mediterranean tour. It was meant to hang in Newstead, his family home, for as long as he was abroad. ${ }^{9}$

The first stop was Portugal, where Byron's judgments, not only about the Portuguese but also about the English themselves, begin. And they are quite negative in both cases: according to Byron, "anything is better than England", a country he only regrets not having quit "sooner". ${ }^{10}$ With the exception of the village of Sintra, "which is perhaps in every respect the most beautiful in Europe", Portugal is none the better: "Lisbon contains little but filthy streets \& more filthy inhabitants", and is "nearly as bad", in Byron's contention, as Gibraltar. ${ }^{11}$ The negative tone is kept in CHP. In the original MS, we get these lines about Lisbon:

'Mid many things that grieve both nose and ee:

For hut and palace smelleth filthily.

In the published version, these are slightly mollified:

'Mid many things unsightly to strange ee;

For hut and palace show like filthily.

The Portuguese continue to fare no better with the nation as a whole, "swol'n with ignorance and pride" or its nationals, "poor, paltry slaves!". ${ }^{12}$ While Byron's impression of the Lisbon filth seems to be justified, his strong judgment on the Portuguese is probably the product of negative personal experiences while in the country, combined with his sharing in an anti-Portuguese current of opinion not uncommon in contemporary England. ${ }^{13}$

Spain is different, and the young lord, who is "enamoured of the country", finds the Spanish men "far superior"14 to the Portuguese — and the Spanish women "far superior to the English women", as he writes in the paragraph which most clearly summarizes his Spanish sympathies:

Seville is a fine town, and the Sierra Morena, part of which we crossed, a very sufficient mountain ... Cadiz, sweet Cadiz! - it is the first spot in the creation. The beauty of its streets and mansions is only excelled by the loveliness of its inhabitants. For, with all national prejudice, I must confess the women of Cadiz are as far superior to the English 
women in beauty as the Spaniards are inferior to the English in every quality that dignifies the name of man. ... I shall return to Spain before I see England, for I am enamoured of the country. ${ }^{15}$

While Byron's negative perception of Spanish men finds no apparent justification, his positive view of Spanish women must without doubt have been influenced by his wellknown flirting episodes with young females like the Beltrán sisters in Seville or Señorita Córdoba in Cadiz, details of which can be read in a letter to his mother ${ }^{16}$, while "The Girl of Cadiz", written when sailing from Gibraltar to Sardinia, stands as his impromptu poetical tribute to women of a description who, apparently, "none abroad, and few at home, / may match." ${ }^{17}$ In CHP however, Byron no longer tones down his admiration for the Spanish (men) by comparing them unfavourably with the English. The "Spanish section" of Canto I (stanzas 35-93) is an all-out display of sympathy for "lovely Spain! renown'd, romantic land!", seen as "the victim" of the French she fights gallantly "on Talavera's plain", in Albuera which became a "glorious field of grief", in Cadiz whose "walls have stood" firmly the Imperial siege, or in Zaragoza where the Maid leads "in Glory's fearful chase." 18 At the same time, "the feast, the song, the revel here abounds", without forgetting the Spanish "black-eyed maids of Heaven, angelically kind". ${ }^{19}$ A remarkably sympathetic attitude for someone who tended to admire Napoleon as much as despise Wellington, only to be explained (I suggest) because Byron, consciously or unconsciously, saw himself reflected in contemporary Spain - a peculiar mix of rebelliousness and joie de vivre. It is not by chance that Seville, "a pleasant city", will be the birthplace and home of Byron's Don Juan.

Byron visits Gibraltar before leaving the Peninsula. A huge and busy Army and Navy barracks at that time, Byron dislikes the Rock, and all he has to say about the British colony on Peninsular soil is that it is "the dirtiest [and] most detestable spot in existence." 20 This negative view leads to a simple lack of interest in $C H P$ : there is a passing reference to "Calpe's straits" ${ }^{21}$ as the hero is sailing East at the start of Canto II, but Gibraltar as such is never mentioned in the poem.

Malta's capital, La Valetta, is the beginning of the second and more substantial part of Byron's tour, the Eastern Mediterranean. The Maltese are "hospitable and pleasant", the traveller writes a few days after having landed in Malta. ${ }^{22}$ In CHP, Malta (and the neighbouring Island of Gozo) deserve special treatment: they are sublimated into "Calypso's isles, / The sister tenants of the middle deep", complete with references to "fair Florence", the celebrated Constance Spencer Smith in the real world, with whom Byron had a brief affair while staying in Malta. ${ }^{23}$ Their later break-up, together with unpleasant experiences in the island on his way back home, arguably explain another change of mood -the cynical tone of "Farewell to Malta", a poem where the island is seen in a negative light, as a queer mixture of "merchants", "mob", "fools", "females" and "red coats", all confused and confined in a "little military hothouse" newly seen by the traveller in a way not unlike Gibraltar. ${ }^{24}$

Byron's first impression of the Greeks, after having landed at Patras some weeks later, is very similar to his still recent impression of the Maltese, and worded in a similar way: the Greeks are "polite and hospitable" according to the poet. ${ }^{25}$ Parallelism 
with Malta likewise obtains in $C H P$ : sublimation is here produced when, on reaching Greece "in a Grecian autumn's gentle eve", what Harold actually hails is "a spot he longed to see", namely "Leucadia's cape afar" which, as the scene of Sappho's tragic death, is paid due homage by the poet. ${ }^{26}$

The young lord's true encounter, however, is with the Albanians. "I like the Albanians much", he writes from Preveza, and this also included the famous (or infamous for many) Ali Pasha, the Albanian leader, very kind and polite to Byron, even though the young lord does not fail to recognize that he was also "a cruel tyrant."27 Later in the same letter, Byron focuses on Viscillie, his newly-acquired Albanian servant and bodyguard, which in turn leads him into making general judgments on the Albanians. In his own words,

His name [Byron servant's] is Viscillie, and, like all the Albanians, he is brave, rigidly honest, and faithful; but they are cruel, though not treacherous, and have several vices but no meannesses. They are, perhaps, the most beautiful race, in point of countenance, in the world; their women are sometimes handsome also, but they are treated like slaves, beaten, and, in short, complete beasts of burden; they plough, dig, and sow. ... The men are all soldiers, and war and the chase their sole occupations. ... I like the Albanians much; they are not all Turks; some tribes are Christians. But their religion makes little difference in their manner or conduct. They are esteemed the best troops in the Turkish service. I ... never found soldiers so tolerable, though I have been in the garrisons of Gibraltar and Malta, and seen Spanish, French, Sicilian, and British troops in abundance.

Byron's sympathy towards Albania is likewise reflected and reinforced in CHP. The "land of Albania, where Iskander rose" is allotted no fewer than 35 stanzas complete with the "Tambourgi!" song, based on Albanian folklore, plus a long final note on the then exotic country and his unique experiences there. ${ }^{28}$ Although "no nation are so detested and dreaded by their neighbours as the Albanese", since "the Greeks hardly regard them as Christians, or the Turks as Moslems", our author contends that as far as his "own experience" goes, he "can speak favourably" of a people whom he calls "turbulent and bold" and reminds him "forcibly" of "the Highlanders of Scotland, in dress, figure, and manner of living." 29 Albania, where very few Englishmen had been previous to Byron's visit, struck him as a complete surprise, the cultural alternative he had been looking for when embarking on his Mediterranean tour -and that, in a sense, he himself was becoming: exotic, remote, different. Significantly, he began writing CHP while in this country. In this light, it comes as no surprise that he would further express his identification with Albania by, back in London, having himself famously portrayed in the "'magnifique' Albanian dresses" he had himself bought there. ${ }^{30}$

Byron spent the next four months exploring continental Greece. Then in the spring of 1810 he sailed to Asia Minor, visiting Smyrna, Ephesus, the Troad and finally staying for two months in Constantinople, the Easternmost limit of his tour. Finally, on his return from Constantinople the young lord lived quite happily for nearly a year in Athens, at the Capuchin Convent, in a cheerful atmosphere of young boys. On his first arrival there he had resided with the Macri girls and had been very happy -allowing for 
the fact that, on the way back, there was no agreement to bring away one of them $!^{31}$ It is in any case remarkable that, the more he settles in Greece, the more he looks down on Britain, which he increasingly refers to as "your country", as when he writes to his lawyer John Hanson,

I have no intention or wish to return to your country \& necessity alone will compel me to do it ... I do not think of my return except for mere necessity, I dislike England, \& the farther I go the less I regret leaving it. ${ }^{32}$

The fact that, at long last, the young lord had recently been made to realize that he was "ruined" surely added to his dislike of Britain. ${ }^{33}$ And the fact that in the Levant Byron could develop his own sexuality -the "old Horatian way" crucially included- much more freely than at home probably added in direct proportion to his liking of the local peoples. ${ }^{34}$ At this stage of his life Byron is fairly sympathetic to the Turks: "I find Turkey better than Spain or Portugal though I was not displeased with them", as his contention is. ${ }^{35}$ This sympathy, however, has its limits. The only direct reference to "Stamboul" in CHP is made in order for the narrator to state that "turbans now pollute Sophia's shrine", which sets the tone for a series of allusions to "the scourge of Turkish hand" that keeps the Greeks subjugated or, as our poet writes, "from birth till death enslav'd". ${ }^{36}$ In this respect, one should not be misled by the longish "Additional note, on the Turks" which Byron inserts at the back of his poem. At first sight the note is highly flattering to the Ottoman Turks:

The Ottomans, with all their defects, are not a people to be despised. Equal, at least, to the Spaniards, they are superior to the Portuguese. If it be difficult to pronounce what they are, we can at least say what they are not: they are not treacherous, they are not cowardly, they do not burn heretics, they are not assassins, nor has an enemy advanced to their capital. ${ }^{37}$

However, when it comes to illustrating this "negative catalogue" of virtues, all the examples given refer to the "provincial" Turks (as he himself calls them) with whom he had been so much friends in Albania, the Morea, Thebes or Athens itself. ${ }^{38}$ On the whole, Byron's experience of Constantinople, the nec plus ultra of his Mediterranean and Levant tour, had not been so pleasant as he had imagined. Having witnessed what daily life was like under an arbitrary and often brutal regime which disdained human life, he also realized how hard it was to socialize with Turkish men ("it is possible to live amongst them twenty years without acquiring information, at least from themselves"), not to mention with Turkish women ("the Turks take too much care of their women to permit them to be scrutinized ... female society is out of the question"). ${ }^{39}$ Significantly, while his reception by Ali Pasha in the (after all) provincial Albania had deserved a wealth of enthusiastic comments in letters to family and friends ${ }^{40}$, the much more splendid (albeit probably less friendly) reception by Sultan Mahmud II in the Porte, which he attended on July 10th, 1810 with the British Ambassador, seems to have left no lasting impression on him and the audience is actually never mentioned in $C H P$, and just in passing in two letters. ${ }^{41}$ 


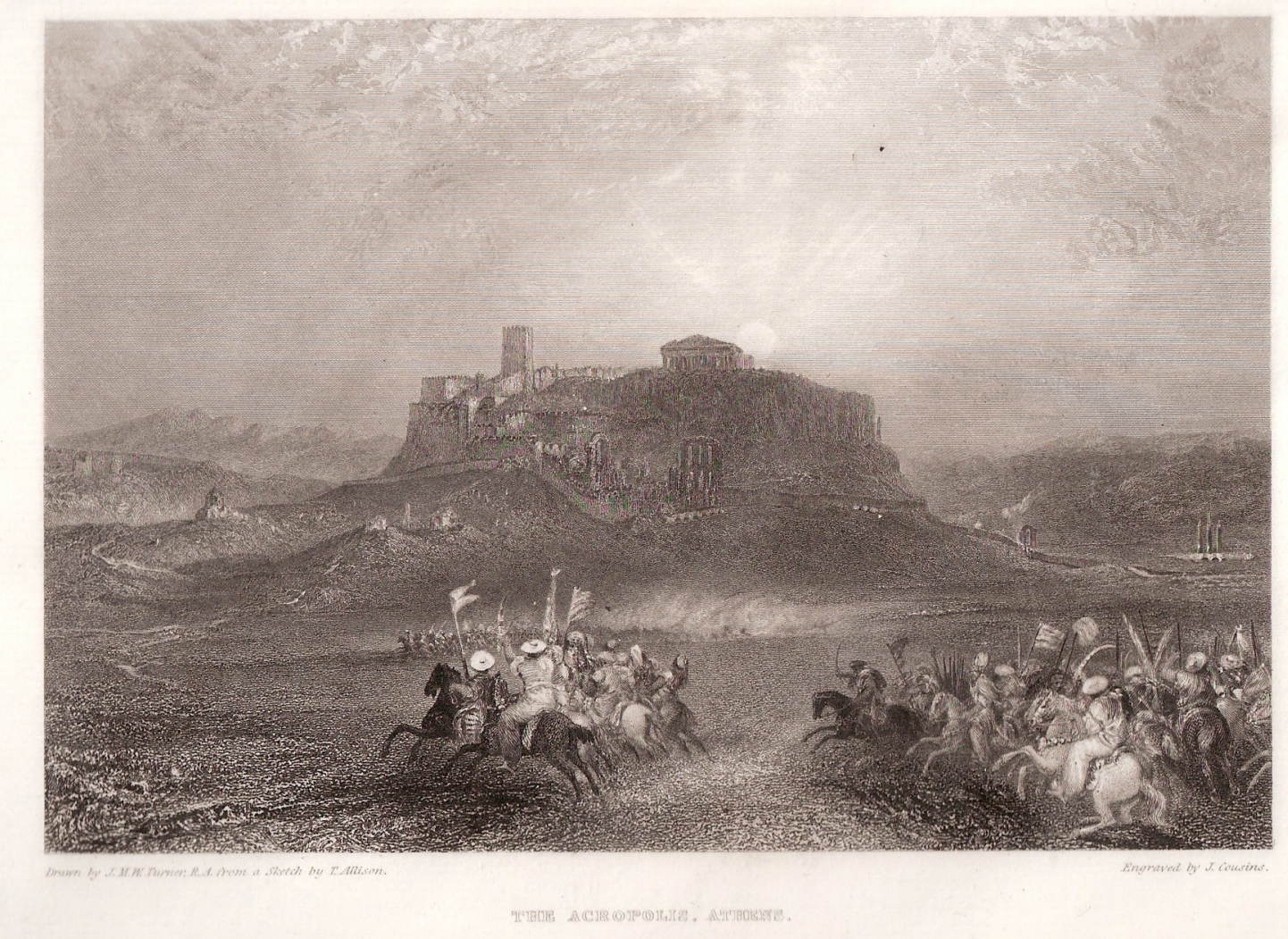

Fig. 1 ‘The Acropolis, Athens’, by J.M.W. Turner, 1832.

The place where Byron stays longest (practically one full year) was Athens, which is also the one he likes best. At the times of Byron's visit Athens was just a small and not very pleasant village: a well-known contemporary print of Athens represents hardly anything other than the Acropolis standing alone, in the middle of a practically empty ground, and the Turkish cavalry riding on the plain. ${ }^{42}$ But he likes the Greek capital well: "I am at Athens again, a place which I think I prefer, upon the whole, to any I have seen." 43 The tone is, however, different in CHP. Here, the expression of personal pleasure gives way to more serious thought. Practically all references to Athens, and to Greece and the Greeks in general, are elegiac in tone:

Ancient of days! august Athena! where,

Where are thy men of might? thy grand in soul? ${ }^{44}$

In addition, criticism is levelled at Lord Elgin's predatory habits ("of all the plunderers ... the last, the worst, dull spoiler"), the ruthless Ottoman rulers of the country ("the scourge of Turkish hand") and even those Greeks who shamefully indulge in the situation (a "degenerate horde") ${ }^{45}$ Byron appears to be becoming conscious of the 
emerging Greek national identity, and of the ruthless and long-standing Turkish oppression. Always interested in languages, during his second stay in Athens Byron took lessons in modern Greek with Ioannis Marmarotouri, a leader who supported independence, and, significantly, soon translated a poem "written by Riga", the protomartyr of Greek independence, "who perished in the attempt to revolutionize Greece."46 Trapped between his relative sympathy for the Turks, and his relative antipathy for the Greeks, at this stage Byron's Philhellenism manifests itself as a compromise position between the two allegiances:

The Greeks will never be independent; they will never be sovereigns as heretofore, and God forbid they ever should! but they may be subjects without being slaves ... There seems to be no great obstacle ... to their becoming a useful dependency, or even a free state with a proper guarantee. ${ }^{47}$

Some of the letters that Byron writes during his second stay in Greece are very clear in their cross-comparisons and judgments. On one occasion he compares the four main national characters he has come across during his Mediterranean tour:

I have also passed some time with the principal Greeks in the Morea and Livadia, and, though inferior to the Turks, they are better than the Spaniards, who, in their turn, excel the Portuguese. $^{48}$

Naturally, Byron's own personal mood is not always the same, and it actually tends to grow worse with time, as he receives more and more disturbing news about his financial situation in Britain. This naturally affects his judgments on national characters. Once, when still in good mood, he produced this 'naughty but funny' comparison:

Albania, indeed, I have seen more of than any Englishman ... for it is a country rarely visited, from the savage character of the natives, though abounding in more natural beauties than the classical regions of Greece ... I see not much difference between ourselves and the Turks, save that we have foreskins and they none, that they have long dresses and we short, and that we talk much and they little.- In England the vices in fashion are whoring \& drinking, in Turkey, sodomy \& smoking, we prefer a girl and a bottle, they a pipe and pathic.- They are sensible people ... ${ }^{49}$

In a more serious vein, he wrote in a note to his first fair copy of $C H P$ :

It must be understood that the Albinese [sic] in common with the Turks and Greeks are addicted to Pederasty though I must say in their favour what must be said for the Turks, that I believe they prefer women, however in Albania their number is small in proportion to the male population. ${ }^{50}$

Other writings include sceptical and gloomy thoughts, as when he contends, "I have seen mankind in various countries and find them equally despicable", or "I'm returning 
home without a hope, and almost without a desire." ${ }^{51}$ One of his most devastating paragraphs to this respect is the following:

I will trouble you no more at present, except to state that all climates and nations are equally interesting to me; that mankind are everywhere despicable in different absurdities; that the farther I proceed from your country the less I regret leaving it, and the only advantage you have over the rest of mankind is the sea, that divides you from your foes; your other superiorities are merely imaginary. I would be a citizen of the world, but I fear some indispensable affairs will soon call me back; and as I left the land without regret, I shall return without pleasure. ${ }^{52}$

This pessimistic attitude becomes more conspicuous when Byron realizes that he has to return home, if only for a period, to try and manage his "unmanageable affairs", as he himself writes. ${ }^{53}$ But all in all, he now considers himself "a citizen of the world", as he also contends and, showing this is not just palaver, before he leaves Athens in 1811 he writes to his mother the precious text which can be chosen as a model for any declaration of educational cosmopolitism. After summarizing and exemplifying the vices of English parochialism in the figure of his servant Fletcher, Byron writes:

I am so convinced of the advantages of looking at mankind instead of reading about them, and the bitter effects of staying at home with all the narrow prejudices of an islander, that I think there should be a law amongst us, to set our young men abroad, for a term, among the few allies our wars have left us. Here I see and have conversed with French, Italians, Germans, Danes, Greeks, Turks, Americans, etc., etc., etc.; and without losing sight of my own, I can judge of the countries and manners of others. Where I see the superiority of England (which, by the by, we are a good deal mistaken about in many things), I am pleased, and where I find her inferior, I am at least enlightened. Now, I might have stayed, smoked in your towns, or fogged in your country, a century, without being sure of this, and without acquiring anything more useful or amusing at home. ${ }^{54}$

With all the evidence above in mind, if we were to set a tentative classification of Byron's national preferences as expressed in his writing of the period, the Albanians and the Turks would attain the top score on the positive scale, followed by the Greeks and by the Spaniards, in that order. On the negative side, the English would get first position, followed by the Portuguese.

Is there an explanation for this? As hinted in previous paragraphs, I think there is, in fact, a multiple explanation. It is common knowledge that the first impression, the initial experiences when visiting a place, often leave a permanent imprint on the visitor. In Portugal, Byron and Hobhouse were mugged by ruffians in the streets of Lisbon. ${ }^{55}$ In Spain however they made friends with local ladies and gentlemen, including a popular idol like general Castaños, the victor of Bailén. ${ }^{56}$ Byron's first impression of Albania and the hospitable Albanians could not be more favourable, and the same happened with the Greeks. The fact that the Greeks, all the same, are considered inferior to the Turks may be related to wider issues of cultural prejudice. In Byron's time and well before (and after!) many "Northerners", including British travellers, thought that the 
present-day Greeks were a degenerate race who could not match the feats of their illustrious predecessors, and in a sense deserved to be under the yoke of the more decisive and deserving Turks. ${ }^{57}$ And of course, there is Orientalism as a cultural issue in its own right. For more than a century in 1809 the Orient had been attractive and fashionable in Christian Europe, with such major works as the French and English translations of the Arabian Nights, Mary Wortley Montagu's enthralling letters from the Embassy in Constantinople, Montesquieu's Lettres Persannes, Johnson's Rasselas, Beckford's Vatheck or the mighty Napoleonic Description de l'Egypte, which first appeared in $1809 .{ }^{58}$ In a letter to Davies from Athens, halfway through his tour, Byron wrote: "I feel happy, I feel free, I can go and I can fly." 59 This is the third reason, or set of reasons, why young Byron likes the Mediterranean. This freedom and happiness he talks about while in Athens he associates with being as far away from Britain as possible. Financial problems, sexual worries, a literary establishment who had yet to admit him, even a conservative government which he hated and, by and large, an English society which as we know he considers full of "narrow prejudices", all combined to produce this attitude which he expresses many times throughout these writings: "I have no wish to return to England", "I will never revisit England", "I will never live in England", "I dislike England", ${ }^{60}$ etc. National sympathies in Byron tend to correlate with the physical and cultural distance with respect to England of the countries concerned.

Whatever the reasons, the consequences of those sympathies with the Levant and the Mediterranean he knew -Turks, Greeks, Spaniards...- are really major ones. On the personal side, when, as he predicted, Byron could not stand Britain any longer, he left the island for good, and went to live for the rest of his life, in what was a voluntary exile, first to Italy (his major pending Mediterranean subject) and then again to Greece -where, even allowing for his frustration at the Greek leaders' internal conflicts and treacherous attitudes, his support of their cause cost him his life. At that mature stage, Byron's Mediterranean preferences had already changed: he may still have been cosmopolitan at heart rather than nationalist, but supporting the Greeks against his formerly admired Turks had been his undeniable choice. It is difficult not to assume that the later expatriate, Philhellenic Byron had its origin in these early Mediterranean experiences.

And of course there is the literature. For some decades before Byron's journey, travel writers had been exploring the fringe Mediterranean areas of the traditional Grand Tour -Robert Southey or William Jacob in the Iberian Peninsula, James Boswell in Corsica, Patrick Brydone in Malta and Sicily, Richard Chandler in Asia Minor- and, significantly, writing their impressions in overtly 'autobiographical' forms such as letters, journals or diaries. ${ }^{61}$ As for Byron, it is clear that without having known and liked the Greeks and the Spaniards he could not possibly have written his captivating CHP, especially cantos I and II, the fictionalized version of his Mediterranean tour. Without having been on the spot, and loved Athens so much, he could not possibly have denounced Lord Elgin's plunder of the Acropolis marbles in CHP, Canto II and in The Curse of Minerva. Without having been so enthusiastic by then about the Albanians and 
the Turks he could not possibly have written his series of "Turkish Tales" in verse that were produced in quick succession between 1813 and 1816: The Giaour, The Bride of Abydos, The Corsair, Lara, or The Siege of Corinth -to which must be added the Hebrew Melodies and, above all, his masterpiece Don Juan, with its starting point in Seville and in "Cadiz, sweet Cadiz". With all these works, which constitute a substantial proportion of his artistic output as a whole, and which were hugely successful with a devoted public, first British and then Pan-European, Byron crucially contributed to prolonging Orientalism in the Western world. Devoted literary disciples like Benjamin Disraeli and Alfred Tennyson would actually travel across the Mediterranean following Byron's steps of $1809 .{ }^{62}$ Well supplied by the Orientalist literature of other great authors like Goethe, Chateaubriand, Victor Hugo, Flaubert or Fitzgerald, Byron's work would thus link up with the sophisticated new wave of literary Orientalism which arrived in Europe one hundred years later with Modernism and Pierre Loti, T.E. Lawrence or Forster in the novel, Tagore and his Nobel Prize, Ezra Pound and many others in poetry. It is difficult not to exaggerate the short, the mid- and the long-term importance of those apparently casual judgments that young Byron made two centuries ago now, about the peoples of what he would rightfully once call "my Mediterranean", with its "cloudless climes and starry skies". 63

\section{Notes}

1. The canonical editions of those writings are respectively George Gordon Byron, Letters and Journals, vols. 1, 2 and 13 [additional letters], edited by Leslie A. Marchand (Cambridge, Mass.: Harvard UP, 1973, 1975, 1994), The Complete Poetical Works, vol. 1, edited by Jerome J. McGann (Oxford: Oxford UP, 1980) and The Complete Miscellaneous Prose, edited by Andrew Nicholson (Oxford: Oxford UP, 1991). From this point on I will refer to said volumes as $B L J$ I, $B L J$ II, $B L J$ XIII, $C P W$ I and $C M P$ respectively. This paper is related to the Spanish I+D+i National Research Project MCI FFI2011-23532.

2. For theoretical aspects as well as different illustrations of the emergence of national stereotypes, see The Discursive Construction of National Identity, edited by Ruth Wodak et al., 2nd. ed. (Edinburgh: Edinburgh UP, 1999), and Imagology: The Cultural Construction and Literary Representation of National Characters: A Critical Survey, edited by Manfred Beller and Joep Leerssen (New York: Rodopi, 2007). The journal National Identities (Routledge) regularly publishes interesting contributions on the topic.

3. The canonical edition of Childe Harold's Pilgrimage [hereafter CHP] is The Complete Poetical Works, vol. 2, edited by McGann (Oxford: Oxford UP, 1980). For the reception of CHP, see Peter W. Graham, 'Byron and the Business of Publishing', in The Cambridge Companion to Byron, edited by Drummond Bone (Cambridge: CUP, 2004), pp. 27-43, especially pp. 30-33.

4. Marchand, Byron: A Portrait (Chicago: U Chicago P, 1970), p. 102; Fiona MacCarthy, Byron: Life and Legend (London: Faber, 2003), pp. 139-140.

5. See McGann ed., CHP, pp. 265-71 and Graham, pp. 31-33 for details. 
6. Standard biographies of Byron include Marchand's monumental Byron: A Biography in 3 vols. (London: Murray, 1957) and its abridged version Byron: A Portrait (see note 4); Benita Eisler, Byron: Child of Passion, Fool of Fame (New York: Knopf, 1999) and (the latest so far) MacCarthy's groundbreaking Byron: Life and Legend (see note 4).

7. Lord Byron's First Pilgrimage, by William A. Borst (New Haven: Yale UP, 1948), was the first study devoted specifically to Byron's tour of 1809-11, only to be surpassed by later biographies (see above, note 6) in minor details. See also Byron and the Mediterranean, edited by Peter Vassallo (Malta: University, 1986) and Byron and the Mediterranean World, edited by Marius B. Raizis (Athens: Hellenic BS, 1995).

8. Unfortunately Byron never published a travelogue of his Mediterranean adventure, but Hobhouse did: on arrival to England, he prepared his Journey through Albania, which saw the public light in London, 1813. There would be a later edition, with a slightly modified title, in 1855.

9. The painting, oil on canvas $(112.5 \times 89.5 \mathrm{~cm})$, now belongs to The Royal Collection, RCIN 402411.

10. To Francis Hodgson, Lisbon 16 July 1809 (BLJ I, pp. 215-216) and to John Hanson, Lisbon 13 July 1809 (BLJ I, 214-215) respectively.

11. To Catherine Gordon Byron, Gibraltar 11 August 1809 (BLJ I, pp. 218-222) and to John Hanson, Gibraltar 7 August 1809 (BLJ I, pp. 217-218) respectively.

12. CHP I, 11. 229-230, 228, 234 respectively.

13. For more details, see J. Almeida Flor, 'A Portuguese Review of Childe Harold's Pilgrimage', in Byron: Portugal, 1977 edited by F. De Mello Moser (Coimbra: Byron Society, 1977), pp. 59-74.

14. To John Hanson, Gibraltar 7 August 1089 (BLJ I, pp. 217-218).

15. To Francis Hodgson, Lisbon 16 July 1809 (BLJ I, pp. 215-216).

16. Gibraltar, 11 August 1809 (BLJ I, pp. 218-222).

17. $C P W$ I, pp. 272-272. The title is editorial.

18. CHP I, 1l. 387, 445, 448, 459, 874 and 575 respectively. Byron saw Agustina Zaragoza i Domènech in Seville and was struck by her feminine appearance, which he was not expecting: See further Borst, Lord Byron's First Pilgrimage, p. 27, and Richard A. Cardwell, "Byron's Romantic Adventures in Spain", in Byron and Latin Culture, edited by Peter Cochran (Newcastle: Cambridge Scholars, 2013), pp. 346-368. This event may have added to his positive view of Spanish women.

19. CHP I, 11. 611, 487 respectively.

20. To John Hanson, Gibraltar 7 August 1809 (BLJ I, pp. 217-218).

21. CHP II, 1. 190. Mons Calpe, one of the Pillars of Hercules, is the Latin name for the Rock of Gibraltar.

22. To Catherine Gordon Byron, Malta 15 September 1809 (BLJ I, pp. 223-224).

23. CHP II, 11. 253, 254, 280 respectively.

24. The poem was first published in Poems on His Domestic Circumstances ... By Lord Byron (1816). The canonical edition is in CPW I, pp. 338-340.

25. To John Hanson, Preveza, 29 September 1809 (BLJ I, pp. 225). It should be remembered that Greece was by then part of the Ottoman Empire and was thus under Turkish rule. Byron will become deeply engaged in the ensuing conflict: see the recent Roderick Beaton, Byron's War: Romantic rebellion, Greek revolution (Cambridge: CUP, 2013). 
26. CHP II, 11. 352, 353, 354 respectively. Byron was, of course, bisexual and, probably, more innately oriented towards homosexuality than towards heterosexuality: See MacCarthy, Byron: Life and Legend, pp. xii-xiii, and below, note 34.

27. To Catherine Gordon Byron, Preveza 12 November 1809 (BLJ I, pp. 226-231).

28. See CHP, pp. 56-68 and, for the note, pp. 192-195.

29. CHP, pp. 192-193. No such comparison obtains in the letters and occasional poems of the tour, where the only reference to the Highlands is made a propos of Sintra in Portugal, said to combine "all the wildness of the Western Highlands with the verdure of the South of France" (BLJ I, p. 218). Massimiliano Demata has studied Byron's views on the Albanians and the Scottish Highlanders in the light of the Scottish Enlightenment: see his "From Caledonia to Albania: Byron, Galt, and the Progress of the Eastern Savage", Scottish Studies Review 2:2 (2001), 61-76, and note 38 below.

30. BLJ I, 231. Byron posed in 1813 for the portrait artist Thomas Phillips (1770-1835). The oil painting, which Phillips completed next year, is now in the British Embassy in Athens. Phillips himself made a replica of the painting in 1835, which is currently on display at London's National Portrait Gallery (NPG cat. 142). The versions of the portrait in small print format (like Finden's, also preserved in the NPG, cat. D7608) would significantly contribute to increase the popularity of this icon of Romantic Orientalism. See Annette Peach, 'Famous in My Time: Publicization of Portraits of Byron during His Lifetime', in Byron: The Image of the Poet, edited by Christine Kenyon-Jones (London: Associated UP, 2008), pp. 57- 67.

31. "I was near bringing away Theresa [Macri] but the mother asked 30000 piastres!" To John Cam Hobhouse, Malta 15 May 1811 (BLJ II, pp. 46).

32. To John Hanson, Patras 24 November 1809 (BLJ I, pp. 233-234). He will use exactly the same formula ("your country") in later letters to Robert Charles Dallas and to Catherine Gordon Byron: See below, notes 52 and 54.

33. "Yours arrived on the first Inst. it tells me I am ruined". To John Hanson, Athens 11th November 1810 (BLJ II, p. 25). For the financial aspects of the tour, see Doris Langley Moore, Lord Byron Accounts Rendered (London: John Murray, 1974), pp. 97-146.

34. "The old Horatian way" (CPW I, p. 283) refers of course to homosexual practice (see above, note 26). Byron's letters and occasional poems of the Mediterranean and Levant tour abound in cryptic references to gay love: $B L J$ I, p. 207; $B L J$ II, pp. 14, 23, 27, 29, 50... See further Louis Crompton, Byron and Greek Love. Homophobia in 19th Century England (London: Faber, 1985), pp. 107-157 and Agustín Coletes Blanco, "Literary Allusion in Byron's Writings of the Mediterranean Tour (1808-1811)", in Byron and Latin Culture, pp. 171-180.

35. To John Hanson, Preveza 12 November 1809 (BLJ I, pp. 231-232).

36. CHP II, 11. 748, 749, 709, 710 respectively.

37. CHP, pp. 209-11, this quotation p. 210.

38. A point overlooked by Demata in his treatment of Byron's Turkish affinities: "Byron, Turkey and the Orient", in The Reception of Byron in Europe Volume II, edited by Cardwell (London: Continuum, 2004), pp. 439-452.

39. $C H P$, p. 209 and $B L J$ I, p. 241, respectively.

40. See BLJ I, pp. 226-231, 233-234, 249-252, 253-254 among others.

41. To Catherine Gordon Byron, Athens 20 July 1810 (BLJ II, pp. 3 and 8), and to Scrope Berdmore Davies (BLJ XI, p. 157). As a contrast, it occupies seven pages in Hobhouse's diary: Hobhouse's Diary, e-edited by Cochran, <http://petercochran.wordpress.com/hobhouses-diary> [accessed 13/11/2013], entry for Tuesday, July 10th, 1810 (pp. 268-275), and eight pages in his Journey to Albania (II, pp. 363-371). See further Cochran, "Introduction: Byron's Orientalism", 
in Byron and Orientalism, edited by Cochran (Newcastle: Cambridge Scholars, 2008), pp. 116120.

42. The cut, "drawn by J.M.W. Turner, R.A., from a sketch by T. Allison", was "engraved by J. Cousins", and "published August, 1832, by J. Murray."

43. To Catherine Gordon Byron, Athens 20 July 1810 (BLJ II, pp. 3-4).

44. CHP II, 11. 10-11.

45. CHP II, 11. 91-94, 709, 791 respectively.

46. Marmarotouri is mentioned in CHP, p. 206. The Riga translation is in CPW I, pp. 33032. On Byron's interest in modern Greek language and literature see Alex Grammatikos, "Byron in the Archives: Modern Greek Print Culture and Byronic Philhellenism", 39th International Byron Conference 2013 London e-Proceedings $<$ http://www.internationalbyronsociety.org > [accessed 7/02/2014].

47. CHP, pp. 201-202. Byron's attitudes to Albanians, Greeks and Turks have been commented on by critics in the area of Balkan studies, such as Tatiana Kuzmic, "Childe Harold's Pilgrimage in the Balkans", Comparative Critical Studies 4:1 (2007), 51-65; Umut Özkırımlı and Spyros A. Sofos, Tormented by History: Nationalism in Greece and Turkey (New York: Columbia UP, 2008), p. 48, or Jim Potts, The Ionian Islands and Epirus: A Cultural History (New York: OUP, 2010), pp. 227-229. These studies focus on CHP and later poems rather than on the letters and occasional poems of the 1809-11 tour. See also Cardwell, "Byron and the Orient: Appropriation or Speculation?" in Byron and Orientalism, pp. 155-176.

48. To Catherine Gordon Byron, Constantinople 28 June 1810 (BLJ I, p. 252).

49. To Henry Drury, Salsette frigate, in the Dardanelles off Abydos, 3 May 1810 (BLJ I, pp. 237-240, this quotation p. 238).

50. This was never printed. See $C P W$ II, p. 198.

51. "Four or five reasons in favour of a change", Malta, 22 May 1811 (BLJ II, pp. 47-48; though included in Marchand's collection, this is a personal note, not a letter, and letter to Francis Hodgson, Volage frigate, at sea, 29 June 1811 (BLJ II, 52-54) respectively.

52. To Robert Charles Dallas, Constantinople 23 June 1810 (BLJ I, 247-249).

53. To John Cam Hobhouse, Malta 15 May 1811 (BLJ II, 44-47).

54. To Catherine Gordon Byron, Athens 14 January 1811 (BLJ II, pp. 34-35).

55. On a note to stanza 21, Canto I of $C H P$, Byron contends that, had they not "fortunately been armed", they would have "adorned a tale instead of telling one" (CHP, p. 188). See further Borst, Lord Byron's First Pilgrimage, pp. 6-20.

56. See letter to Catherine Gordon Byron, Gibraltar 11 August 1809 (BLJ I, pp. 218-222).

57. See Nigel Leask, "Byron and the Eastern Mediterranean: Childe Harold II and the "polemic of Ottoman Greece", in Cambridge Companion to Byron, pp. 99-117.

58. For more examples and details, see the second part of Edward W. Said's classic Orientalism, 2nd ed. (London: Penguin, 2003); Saree Makdisi, 'Literature, National Identity, and Empire', in The Cambridge Companion to English Literature 1740-1830, edited by Thomas Keymer and Jon Mee (Cambridge: Cambridge UP, 2004), pp. 61-79 and Diego Saglia, 'Orientalism', in A Companion to European Romanticism, edited by Michael Ferber (Oxford: Blackwell, 2005), pp. 467-485.

59. To Scrope Berdmore Davies, Patras, 31 July 1810 (BLJ XI, pp. 157-158).

60. To John Hanson, Preveza 12 November 1809 (BLJ I, pp. 231-232), and Patras, 24 November 1809 (BLJ I, pp. 233-234).

61. For more details, see Elizabeth A. Bohls, "Introduction" to Travel Writing 1700-1830: An Anthology, edited by E.A. Bohls and Ian Duncan (Oxford: Oxford UP, 2005), pp. xiii-xxviii, 
xxiii-xxiv especially; James Buzard, "The Grand Tour and After (1660-1840)", in The Cambridge Companion to Travel Writing, edited by Peter Hulme and Tim Youngs (Cambridge: CUP, 2002), pp. 37-52, and Leask, "Byron and the Eastern Mediterranean", pp. 102-103.

62. See David Mitchell, Travellers in Spain (Fuengirola: Santana, 2004), pp. 58-59 and Saglia, Lord Byron e le maschere della scrittura (Roma: Carocci, 2009), pp. 59-63. The latest 'literary disciple' to follow Byron's Mediterranean steps is probably the Dutch novelist Tessa de Loo and her travelogue of significant title, In Byron's Footsteps (London: Armchair Traveller, 2011), which focuses on Albania.

63. Letter to Thomas Moore, Hastings, 3 August 1814, and poem 'She Walks in Beauty', from Hebrew Melodies (1814).

\section{References}

Almeida Flor, J. (1977): “A Portuguese Review of Childe Harold's Pilgrimage.' In F. De Mello Moser, ed., Byron: Portugal, 1977. Coimbra: Byron Society, 59-74.

Beaton, Roderick (2013): Byron's War: Romantic rebellion, Greek revolution. Cambridge: CUP.

Beller, Manfred and Joep Leerssen (eds.)(2007): Imagology: The Cultural Construction and Literary Representation of National Characters: A Critical Survey. New York: Rodopi.

Bohls, Elizabeth A. (2005): "Introduction." In E.A. Bohls and I. Duncan, eds., Travel Writing 1700-1830: An Anthology. Oxford: Oxford UP, xiii-xxiv.

Bone, Drummond (ed.)(2004): The Cambridge Companion to Byron. Cambridge: CUP.

Borst, William A. (1948): Lord Byron's First Pilgrimage. New Haven: Yale UP.

Buzard, James (2002): "The Grand Tour and After (1660-1840)." In P. Hulme and T. Youngs, eds., The Cambridge Companion to Travel Writing. Cambridge: CUP, 37-52.

Cardwell, Richard A. (2008): "Byron and the Orient: Appropriation or Speculation?" In P. Cochran, ed., Byron and Orientalism. Newcastle: Cambridge Scholars, 155-176.

------- (2013): “Byron's Romantic Adventures in Spain.” In P. Cochran, ed., Byron and Latin Culture. Newcastle: Cambridge Scholars, 346-368.

Cochran, Peter (2008): "Introduction: Byron's Orientalism." In P. Cochran, ed., Byron and Orientalism. Newcastle: Cambridge Scholars, 116-120.

Cochran, Peter (ed.)(2008): Byron and Orientalism. Newcastle: Cambridge Scholars.

-------- (2009): Hobhouse's Diary <http://petercochran.wordpress.com/hobhouses-diary> [accessed 13/11/2013].

------- (2013): Byron and Latin Culture. Newcastle: Cambridge Scholars.

Coletes Blanco, Agustín (2013): "Literary Allusion in Byron's Writings of the Mediterranean Tour (1808-1811).” In P. Cochran, ed., Byron and Latin Culture. Newcastle: Cambridge Scholars, 171-180.

Crompton, Louis (1985): Byron and Greek Love. Homophobia in 19th Century England. London: Faber.

Demata, Massimiliano (2001): 'From Caledonia to Albania: Byron, Galt, and the Progress of the Eastern Savage.' Scottish Studies Review 2:2, 61-76.

(2004): 'Byron, Turkey and the Orient'. In R. Cardwell, ed., The Reception of Byron in Europe Volume II. London: Continuum, 439-452.

Eisler, Benita (1999): Byron: Child of Passion, Fool of Fame. New York: Knopf. 
Graham, Peter W. (2004): "Byron and the Business of Publishing." In D. Bone, ed., The Cambridge Companion to Byron. Cambridge: CUP, 27-43.

Grammatikos, Alex (2013): "Byron in the Archives: Modern Greek Print Culture and Byronic Philhellenism." 39th International Byron Conference 2013 London e-Proceedings $<\mathrm{http}: / /$ www.internationalbyronsociety.org > [accessed 7/02/2014].

Hobhouse, John Cam (1813). A Journey through Albania and other provinces of Turkey in Europe and Asia, to Constantinople, during the years 1809 and 1810. London: Cawthorn.

Kuzmic, Tatiana (2007): "Childe Harold's Pilgrimage in the Balkans." Comparative Critical Studies 4(1): 51-65.

Leask, Nigel (2004): "Byron and the Eastern Mediterranean: Childe Harold II and the "polemic of Ottoman Greece." In D.Bone, ed., The Cambridge Companion to Byron. Cambridge: CUP, 99-117.

Loo, Tessa de (2011): In Byron's Footsteps. London: Armchair Traveller.

MacCarthy, Fiona (2003): Byron: Life and Legend. London: Faber.

Makdisi, Saree (2004): 'Literature, National Identity, and Empire.' In T. Keymer and J. Mee, eds., The Cambridge Companion to English Literature 1740-1830. Cambridge: CUP, 6179.

Marchand, Leslie A. (1957): Byron: A Biography. 3 vols. London: Murray. (1970): Byron: A Portrait. Chicago: U Chicago P.

Marchand, Leslie A. (ed.)(1973): Letters and Journals. By George Gordon Byron, Lord Byron. 13 vols. Cambridge, Mass.: Harvard UP. Vol. 1.

(1975): Letters and Journals. By George Gordon Byron, Lord Byron. 13 vols. Cambridge, Mass.: Harvard UP. Vol. 2.

(1994): Letters and Journals. By George Gordon Byron, Lord Byron. 13 vols. Cambridge, Mass.: Harvard UP. Vol. 13.

McGann, Jerome J. (ed.)(1980): The Complete Poetical Works. By George Gordon Byron, Lord Byron. 7 vols. Oxford: Oxford UP. Vol. 1.

------- (1981): The Complete Poetical Works. By George Gordon Byron, Lord Byron. 7 vols. Oxford: Oxford UP. Vol. 2.

Mitchell, David (2004): Travellers in Spain. Fuengirola: Santana.

Moore, Doris Langley (1974): Lord Byron Accounts Rendered. London: Murray.

Nicholson, Andrew (1991): The Complete Miscellaneous Prose. By George Gordon Byron, Lord Byron. Oxford: Oxford UP.

Özkırıml1, Umut and Spyros A. Sofos (2008): Tormented by History: Nationalism in Greece and Turkey. New York: Columbia UP.

Peach, Annette (2008): "Famous in My Time: Publicization of Portraits of Byron during His Lifetime." In C. Kenyon-Jones, ed., Byron: The Image of the Poet. London: Associated UP, 57- 67.

Potts, Jim (2010): The Ionian Islands and Epirus: A Cultural History. New York: OUP.

Raizis, Marius B. (ed.)(1995): Byron and the Mediterranean World. Athens: Hellenic BS.

Saglia, Diego (2005): "Orientalism". In M. Ferber, ed. A Companion to European Romanticism. Oxford: Blackwell, 467-485.

------- (2009): Lord Byron e le maschere della scrittura. Roma: Carocci.

Said, Edward W. (2003): Orientalism, 2nd ed. London: Penguin.

Vassallo, Peter (ed.)(1986): Byron and the Mediterranean. Malta: University.

Wodak, Ruth et al. (eds.)(1999): The Discursive Construction of National Identity, 2nd. ed. Edinburgh: Edinburgh UP. 